\title{
Paroksismal Noktürnal
}

Hemoglobinüride İmmünfenotipleme Çalışmalarının Kliniğe Yansıması: Tek Merkez Deneyimi

\section{Clinical Reflection of Immunophenotyping in Paroxysmal Nocturnal Hemoglobinuria: Experience af a Single Center}

\author{
Uğur ŞAHIN ${ }^{1}$, Mustafa MERTER ${ }^{2}$, Zehra NARLI ÖZDEMIR ${ }^{3}$, Klara DALVA ${ }^{3}$, \\ Sinem CiVRiZ BOZDAĞ ${ }^{3}$, Meltem KURT YÜKSEL ${ }^{3}$, Pervin TOPÇUOĞLU ${ }^{3}$, \\ Önder ARSLAN ${ }^{3}$, Muhit ÖZCAN³ ${ }^{3}$, Taner DEMIRER ${ }^{3}$, Meral BEKSAÇ3${ }^{3}$, \\ Osman ILHAN ${ }^{3}$, Hamdi AKAN ${ }^{3}$, Günhan GÜRMAN³ , Selami Koçak TOPRAK ${ }^{3}$ \\ ${ }^{1}$ Yıldırım Beyazıt Üniversitesi, Yenimahalle Eğitim ve Araştırma Hastanesi Hematoloji Kliniği, \\ Ankara, Türkiye \\ ${ }^{2}$ Fırat Üniversitesi Tıp Fakültesi, Hematoloji Bilim Dalı, Elazı̆̆, Türkiye \\ ${ }^{3}$ Ankara Üniversitesi Tıp Fakültesi, Hematoloji Bilim Dalı, Ankara, Türkiye
}

\section{ÖZET}

Amaç: Paroksismal noktürnal hemoglobinüri $(\mathrm{PNH})$, bir veya birden fazla hematopoietik kök hücrede PIG-A geninde ortaya çıkan kazanılmış somatik mutasyon sonucu gelişen, malign olmayan nadir bir klonal hastalıktır. Hastalığın önde gelen bulguları, kompleman ilişkili intravasküler hemoliz, tromboz ve sitopenilere yatkınlıktır. Günümüzde floresan işaretli inaktif toksin aerolizin testi (FLAER) tabanlı akım sitometrik çalışmalar (ASÇ) PNH tanısında önemli bir yer edinmiştir. Bu retrospektif çalışmada kliniğimizde takip edilen PNH hastalarının tanısal özelliklerinin hastalık özellikleri ile birlikte tanımlanması amaçlanmıştır.

Hastalar ve Yöntem: Kliniğimizde PNH şüphesiyle Kasım 2007 ve Temmuz 2014 arasında hastalardan istenen ASÇ sonuçları retrospektif olarak değerlendirildi. Sonuçlar CD55 ve CD59 negatif bulunan granülosit ve monositlerin yüzdesi olarak verildi. Tanımlayııı istatistiklerin yanı sıra PNH klonu büyüklükleri ile düzeltilmiş retikülosit, serum laktat dehidrojenaz, hemoglobin, haptoglobin ve indirekt bilirubin düzeyleri arasındaki ilişki analiz edildi.

Bulgular: Belirtilen tarihler arasında toplam 175 hastada PNH şüphesiyle ASÇ yapıldı. FLAER yöntemi bu çalışmaların 136 (\%77.7)'sında kullanıldı. Hastaların 39 (\%22.3)'unda PNH klonu izlendi. Bunların 27 (\%69.2)'sinde klasik PNH ve 12 (\%30.8)'sinde diğer kemik iliği hastalıklarına eşlik eden PNH olduğu görüldü. Hastaların \%48.7 ( $n=19)$ 'sinde eritrosit transfüzyonu ihtiyacı mevcuttu. Trombotik olaylar, hastaların \%20.5 ( $n=8$ )'inde izlendi. Hiçbir hastada lösemik transformasyon görülmedi. Trombotik olaylar, klasik PNH'si olan hastalar arasında, sadece klon büyüklüğü > \%50 olan hastalarda izlendi. Klon büyüklüğü ile (hem granülosit, hem de monosit klonları) düzeltilmiş retikülosit ve serum laktat dehidrojenaz düzeyleri arasında pozitif korelasyon izlendi (sırasıyla, granülositler için $p=0.001$ ve $p<0.001$, monositler için $p=0.001$ ve $p<0.001$ ).

Sonuç: PNH hastalarının tanı ve takiplerinde ASÇ önemli bir yöntemdir. Klon büyüklüğü hastalığın şiddetini ve klasik PNH'de tromboz riskini değerlendirmede kullanılabilir. Diğer kemik iliği hastalıklarına eşlik eden PNH'si olan hastalarda klon büyüklükleri genellikle küçük olup klasik PNH'de izlenen komplikasyonlar nadirdir.

Anahtar Sözcükler: Paroksismal noktürnal hemoglobinüri; Akım sitometri

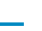




\section{ABSTRACT}

Objective: Paroxysmal nocturnal hemoglobinuria (PNH) is a rare non-malignant clonal disease that occurs as a result of acquired somatic mutation in the PIG-A gene in one or more hematopoietic stem cells. The major findings include complement-associated intravascular hemolysis, thrombosis and cytopenias. Fluorescent labeled inactive toxin aerolysis (FLAER) based flow cytometric studies (FCS) have an important role in diagnosis. This retrospective study aimed to describe the diagnostic features of PNH patients followed up in our clinic with their disease characteristics.

Patients and Methods: The results of FCS requested between November 2007 and July 2014 were retrospectively evaluated. The results were given as a percentage of granulocytes and monocytes found negative for CD55 and CD59. In addition to descriptive statistics, the relationship between PNH clone size, corrected reticulocyte count, serum lactate dehydrogenase, hemoglobin, haptoglobin and indirect bilirubin levels was analyzed.

Results: A total of 175 FCS were included. FLAER was used in 136 (77.7\%). PNH clone was observed in 39 (22.3\%). Of these, 27 (69.2\%) were classical PNH and 12 (30.8\%) had PNH associated with other bone marrow diseases. Erythrocyte transfusions were required in $48.7 \%$ ( $\mathrm{n}$ $=19$ ). Thrombotic events were observed in $20.5 \%(n=8)$. Leukemic transformation was not observed. Thrombotic events were observed only in patients with clone size $>50 \%$. Corrected reticulocyte and serum lactate dehydrogenase levels positively correlated with clone size (both granulocytes and monocyte clones) ( $p=0.001$ and $p<0.001$ for granulocytes, $p=0.001$ and $p<0.001$ for monocytes, respectively).

Conclusion: FCS is an important method in the diagnosis and follow-up of PNH patients. Clone size can be used to assess the severity of the disease and the risk of thrombosis in classical PNH. In patients with PNH associated with other bone marrow diseases, clone sizes are usually small and complications seen in classical PNH are rare.

Key Words: Paroxysmal nocturnal hemoglobinuria; Flow cytometry

\section{GíRiş}

Paroksismal noktürnal hemoglobinüri (PNH), bir veya birden fazla hematopoietik kök hücrede PIG-A geninde ortaya çıkan kazanılmıs somatik mutasyon sonucu gelişen, malign olmayan nadir bir klonal hastalıktır. Etkilenen kök hücrelerden köken alan hücrelerde glikozil fosfatidil inozitole bağlanan proteinler (GPi-BP) eksiktir. Bu proteinler arasında CD55 ve CD59 gibi kompleman düzenleyici proteinler ve CD16, CD24, CD52, CD58, CD66b/67, CD73, CD87, CD90 ve CD108 gibi diğer hücre zarı proteinleri yer almaktadır (1). Eritrositler üzerinde CD55 ve CD59'un bulunmaması, hastalığın önde gelen bulgusu olan kompleman ilişkili intravasküler hemolize yol açmaktadır $(2,3)$. Bu membran proteinlerinin trombositler ve granülositlerde (nötrofil ve monositler) de eksik olması, hastalarda tromboz ve sitopenilere yatkınlık oluşturmaktadır $(2,4)$. PNH kemik iliği yetmezliği ile seyreden aplastik anemi gibi hastalıklarla birlikte sık olarak görülmektedir (5). Hastalığa bağlı morbidite ve mortalitenin en önemli sebebi trombofilidir (4). Sükroz hemoliz testi ve asit Ham testi gibi eritrosit hemolizine dayalı tanısal testlerin yerini günümüzde akım sitometrik çalışmalar (ASÇ) almıştır (2). Önceleri GPi-BP'lerin (CD55 ve CD59) protein kısmına bağlanan monoklonal antikorlar kullanılmaktayken, son zamanlarda GPI çıpasının glikan kısmına bağlanan floresan proaerolisin moleküllerinin ölçümüne dayalı floresan işaretli inaktif toksin aerolizin testi (FLAER) tabanlı uygulamalar, PNH tanısında önemli bir yer edinmiştir (6). Bu retrospektif çalışmada kliniğimizde takip edilen PNH hastalarının tanısal özelliklerini hastalık özellikleri ile birlikte tanımlamayı amaçladık.

HASTALAR ve YÖNTEM
Ankara Üniversitesi Tıp Fakültesi Hematoloji Bilim Dalı Kliniği'nde PNH şüphesiyle Kasım 2007 ve Temmuz 2014 tarihleri arasında hastalardan istenen ASÇ sonuçları retrospektif olarak değerlendirildi. Merkezimizde FLAER uygulamasının Aralık 2011 tarihinden itibaren kullanılmaya başlanması nedeniyle bu tarihten sonra elde edilen ASÇ sonuçlarında her iki yöntem birlikte kullanıldı. Tüm ölçümler Beckman Coulter ${ }^{\circledR}$ Navios 3 lazer/10 renk akım sitometri cihazı ile yapıldı. PNH klonlarının tanımlanmasında daha önce tanımlanmış olan standart yöntemler kullanıldı (7). Eritrositlerdeki klonların tanımlanması için hastalardan 24 saat içinde alınmış olan EDTA ile antikoagüle edilmiş $2 \mathrm{~mL}$ venöz kan örnekleri CD235a-FITC veya CD59-PE ile boyandı. CD55 ve CD59 ekspresyonları çalışılarak ekspresyonlarına göre eritrosit tiplerinin (tip 1, 2 ve 3) dağılımları da yüzde olarak verildi. Granülosit ve monositlerdeki klonların tanımlanmaSı için hastalardan 24 saat içinde alınmış olan kan örnekleri FLAER-Alexa488 (Cedarlane Labs), CD24-PE, CD15-PC5, CD64-PC7, CD14-APC700 ve CD45-KrO ile boyandı. CD45 ile kapılama yapıldıktan sonra nötrofil klonları CD15 ifadesine göre tanımlandı. PNH nötrofilleri, FLAER-negatif/CD24-negatif olarak belirlendi. Monosit klonları CD64 ifadesine göre tanımlandı. PNH monositleri, FLAER-negatif/CD14-negatif olarak belirlendi. Nötrofillerde, hem FLAER, hem de CD24 ekspresyonunda; monositlerde, hem FLAER, hem de CD14 ekspresyonunda \%1'den fazla azalma saptanması, PNH fenotipi için eşik değer olarak kabul edildi.

Test sonuçlarına göre hastalık dağıımları sayı ve yüzde olarak verildi. Normal dağılımı olmayan, ordinal ve nominal değişkenler için ortanca ve minimum-maksimum değerler verildi. PNH klonu büyüklükleri (hem granülosit, hem de 
monosit klonları) ile düzeltilmiş retikülosit, serum laktat dehidrojenaz, hemoglobin, haptoglobin ve indirekt bilirubin düzeyleri arasındaki ilişki analiz edildi. İlişkili bulunan değişkenler arasındaki ilişkinin gücü Pearson korelasyon katsayısı ile belirtildi. Tüm istatistiksel hesaplamalarda IBM $^{\oplus}$ SPSS $^{\oplus}$ Statistics 23.0 yazılımı kullanıldı ve $p<0.05$ olması istatistiksel olarak anlamlı kabul edildi.

\section{BULGULAR}

Belirtilen tarihler arasında toplam 175 hastada PNH şüphesiyle ASÇ yapıldı. FLAER yöntemi bu çalışmaların 136 (\%77.7)'sında kullanıldı. Hastaların 39 (\%22.3)'unda PNH klonu izlendi. Bunların 27 (\%69.2)'sinde klasik $\mathrm{PNH}$ ve 12 (\%30.8)'sinde diğer kemik iliği hastalıklarına eşlik eden PNH olduğu görüldü. PNH klonu pozitif bulunan hastalar arasında PNH'nin eşlik ettiği kemik iliği bozuklukları, aplastik anemi $(n=9)$ ve miyelodisplastik sendrom $(n=3)$ olarak saptandı. Ortanca tanı yaşı klasik PNH için 31 (18-82), diğer kemik iliği hastalıklarına eşlik eden PNH için 35 (18-77) idi (Tablo 1).

Olguların 136 (\%77.7)'sında PNH klonu saptanmadı. PNH klonu saptanmayan hastalara, tanımlanmamış anemi ( $\mathrm{n}=$ $34, \% 19.4)$, diğer tanımlanmamış sitopeni $(n=30, \% 17.2)$, PNH dışı hemolitik anemi $(n=7, \% 4.0)$, miyelodisplastik sendrom ( $n=23, \% 13.1)$, aplastik anemi $(n=9, \% 5.1)$, miyelofibrozis $(n=1, \% 0.6)$, lösemi $(n=7, \% 4.0)$, lenfoma $(n=3$, $\% 1.7)$, trombotik olay $(n=14, \% 8.0)$, romatolojik hastalık ( $n=$ 4, \%2.3) tanıları konmuş olup hastaların \%2.3 ( $n=4)^{\prime}$ ünün herhangi bir tanısı bulunmamaktaydı.

PNH klonu saptanan hastaların \%48.7 $(n=19)$ 'sinde eritrosit transfüzyonu ihtiyacı mevcuttu. Trombotik olaylar, hastaların \%20.5 ( $n=8)$ 'inde izlendi. Hiçbir hastada lösemik transformasyon görülmedi. Aplastik anemisi olan bir hastada bir yıllık takip sonrası ASÇ ile PNH klonunun pozitifleştiği görüldü.
Trombotik olaylar, klasik PNH'si olan hastalar arasında, sadece klon büyüklüğü \%50'den yüksek olan hastalarda izlendi. Klasik PNH'si olan hastalarda tromboz gelişimi için eşlik eden başka bir risk faktörü bulunmazken, diğer kemik iliği hastalıklarına eşlik eden PNH tanısı ile izlenmekteyken trombozu olan iki hastada immobilizasyon ve gebelik gibi eşlik eden ek risk faktörleri mevcuttu (Tablo 1). Klon büyüklüğünün (hem granülosit, hem de monosit klonları) düzeltilmiş retikülosit ve serum laktat dehidrojenaz düzeyleri ile pozitif korelasyonu olduğu görüldü (sırasıyla, granülositler için $p=0.001$ ve $p<0.001$, monositler için $p=0.001$ ve $p<$ 0.001) (Şekil 1,2).

PNH klonu pozitif bulunan hastaların tedavisinde ekulizumab ( $n=12, \% 30.8)$, allojenik kök hücre nakli $(n=13$, \%33.3) ve tedavisiz izlem/diğer yöntemler (siklosporin, steroidler, anti-timosit globulin, danazol) ( $n=16, \% 41.0)$ kullanıldığı görüldü.

\section{TARTIŞMA ve SONUÇ}

PNH hastalarının tanı ve takiplerinde ASÇ önemli bir yöntemdir. Yüksek tanısal hassasiyetinin yanı sıra klon büyüklüğünü göstererek hastalık prognozunun önceden tahmin edilmesinde de faydalı olmaktadır. LDH ve retikülosit sayısı gibi hemoliz parametreleri ve tromboz sıklığında artış ile ilişkili olduğunu gözlemlediğimiz klon büyüklüğü, klasik PNH'de hastalığın şiddetini ve tromboz riskini değerlendirmede kullanılabilir. Klon büyüklüğünün trombozu öngörebileceğini bildiren başka yayınlar da mevcuttur (8). Ayrıca klon büyüklüğündeki artışın karın ağrısı, hemoliz, özefageal spazm ve erektil disfonksiyon ile de ilişkili olabileceği bildirilmektedir (7).

Diğer kemik iliği hastalıklarına eşlik eden PNH'si olan hastalarda klon büyüklükleri genellikle küçük olup klasik PNH'de izlenen komplikasyonlar nadirdir (Tablo 1). Ancak aplastik anemi ve miyelodisplastik sendromda hastalık

Tablo 1. PNH klonu saptanan olguların genel özellikleri

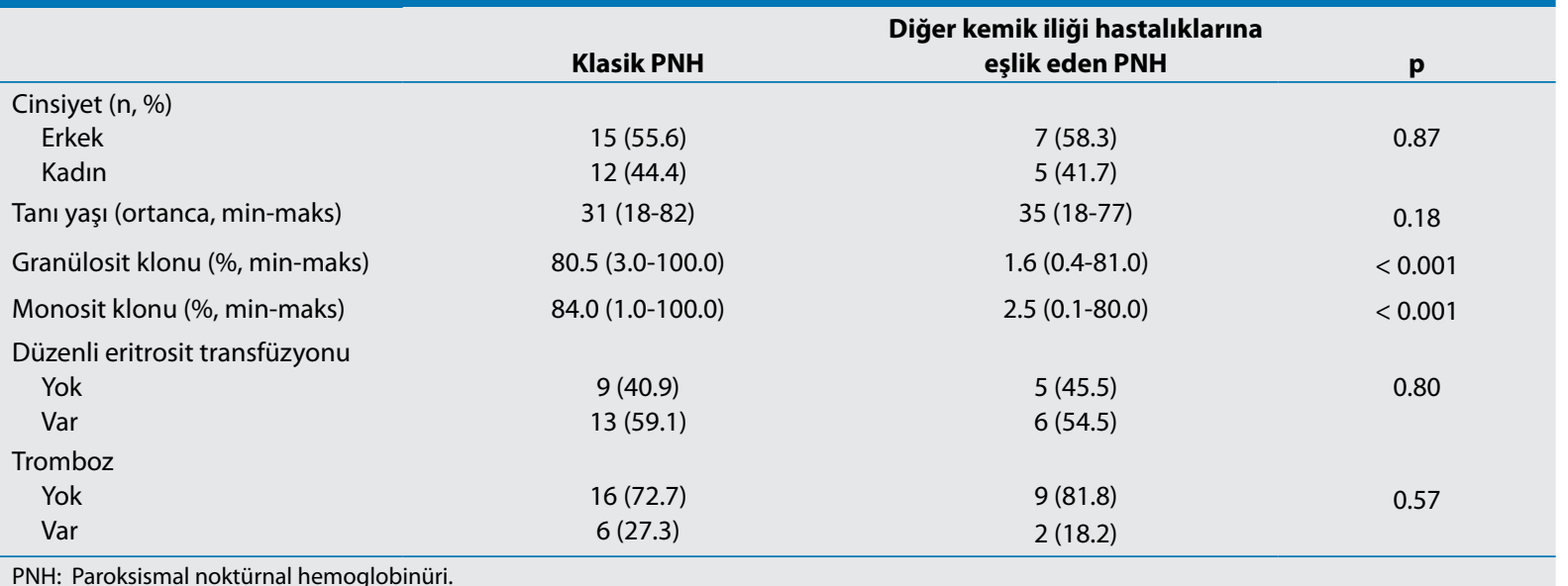



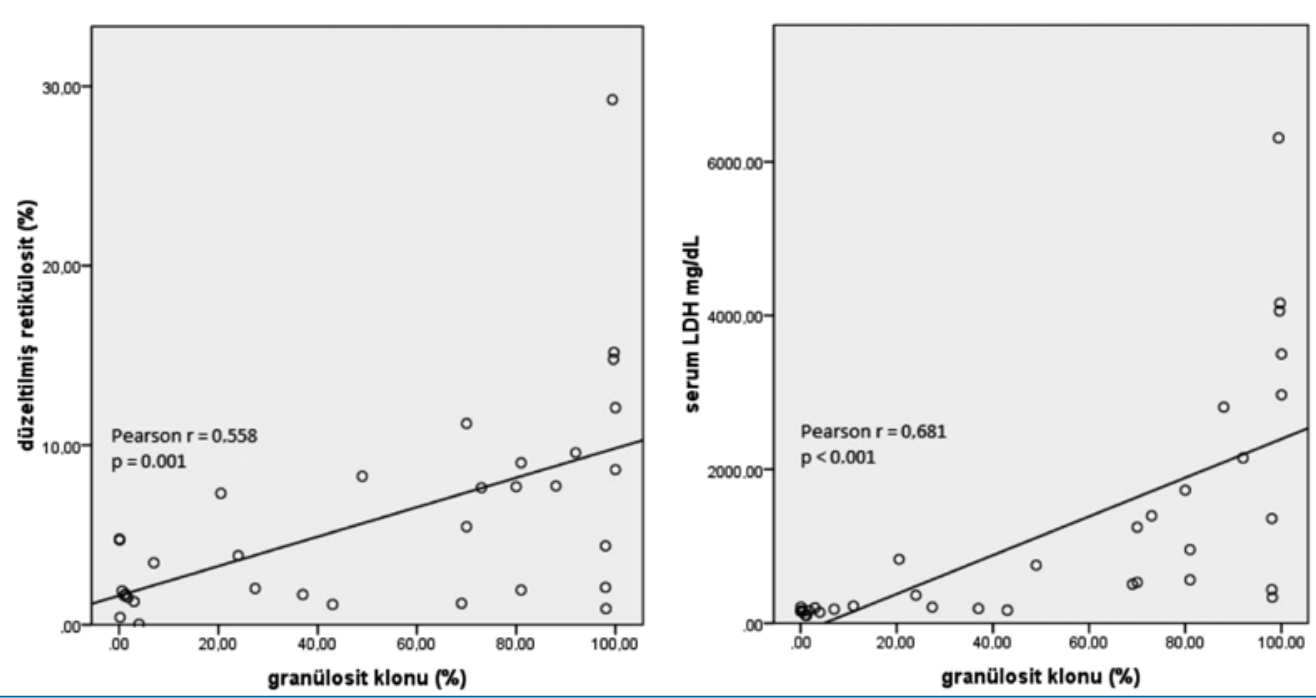

Şekil 1. Granülosit klon büyüklüğ̈ ile düzeltilmiş retikülosit yüzdesi ve serum LDH arasındaki korelasyon.
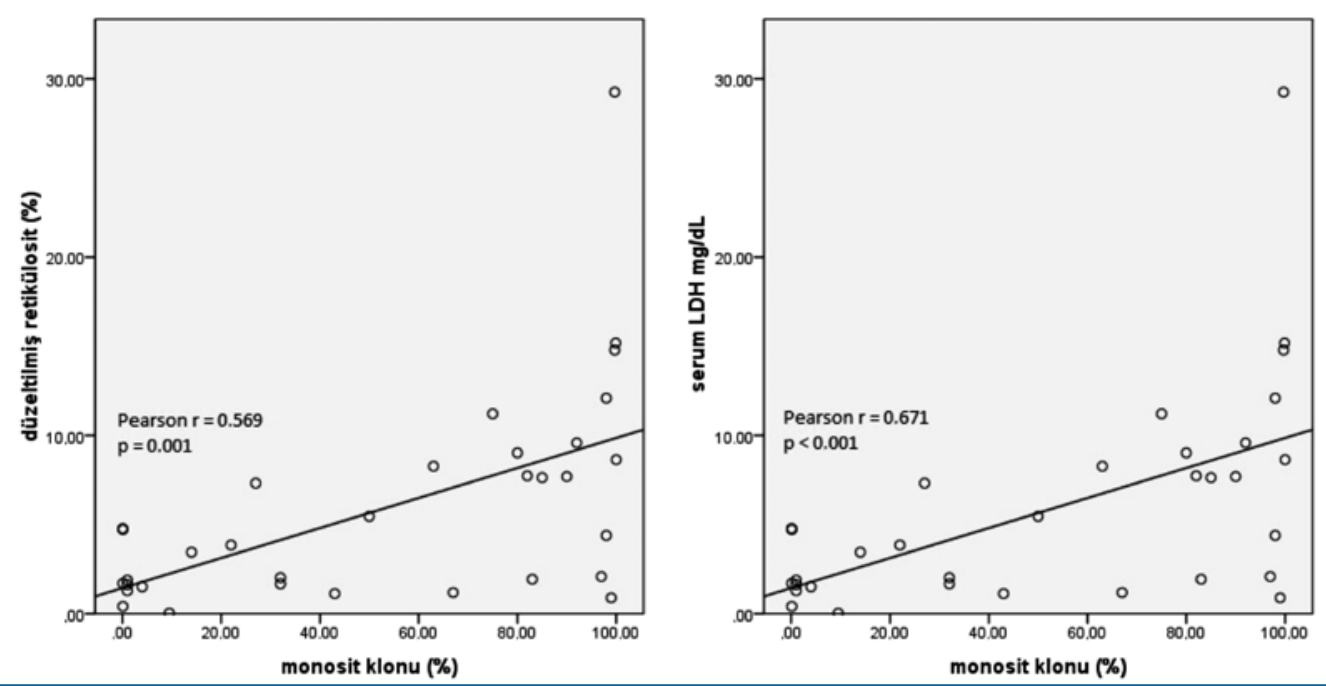

Şekil 2. Monosit klon büyüklüğü ile düzeltilmiş retikülosit yüzdesi ve serum LDH arasındaki korelasyon.

seyri süresince PNH gelişebilir ve bu durum klon büyüklüğündeki artış gösterilerek tespit edilebilir. Bu sebeple, aplastik anemisi ve miyelodisplastik sendromu olan seçilmiş hastalarda, özellikle de tedaviye yanıtsızlık veya beklenmeyen komplikasyonlar ortaya çıktığında PNH tetkiki için ASÇ kullanımı düşünülebilir.

\section{ÇIKAR ÇATIŞMASI}

Yazarların çıkar çatışması bulunmamaktadır.

\section{MALI AÇIKLAMA}

Çalışma için doğrudan veya dolaylı mali destek alınmadı. Çalışma ile ilgili herhangi bir firma veya kişi ile ilgili ticari bağlantı yoktur.

\section{YAZAR KATKISI}

Literatür taranması: UŞ, MM, ZNÖ; Verilerin toplanması: UŞ, MM, ZNÖ, KD, SCB, MKY, PT, ÖA, MÖ, TD, MB, Öi, HA, GG; Makalenin yazımı: UŞ, MM, ZNÖ, KD, SKT.

\section{KAYNAKLAR}

1. Parker C, Omine M, Richards S, Nishimura J, Bessler M, Ware R, et al; International PNHIG. Diagnosis and management of paroxysmal nocturnal hemoglobinuria. Blood 2005;106:3699-709.

2. Nishimura J, Kanakura $Y$, Ware RE, Shichishima T, Nakakuma $H_{\text {, }}$ Ninomiya $\mathrm{H}$, et al. Clinical course and flow cytometric analysis of paroxysmal nocturnal hemoglobinuria in the United States and Japan. Medicine (Baltimore) 2004;83:193-207. 
3. Hillmen P, Hall C, Marsh JC, Elebute M, Bombara MP, Petro BE, et al. Effect of eculizumab on hemolysis and transfusion requirements in patients with paroxysmal nocturnal hemoglobinuria. $\mathrm{N}$ Engl J Med 2004;350:552-9.

4. Hillmen P, Lewis SM, Bessler M, Luzzatto L, Dacie JV. Natural history of paroxysmal nocturnal hemoglobinuria. $N$ Engl J Med 1995;333:1253-8.

5. Nakakuma $\mathrm{H}$, Nagakura S, Iwamoto $\mathrm{N}$, Kawaguchi T, Hidaka M, Horikawa $\mathrm{K}$, et al. Paroxysmal nocturnal hemoglobinuria clone in bone marrow of patients with pancytopenia. Blood 1995;85:13716.
6. Brodsky RA, Mukhina GL, Li S, Nelson KL, Chiurazzi PL, Buckley JT, et al. Improved detection and characterization of paroxysmal nocturnal hemoglobinuria using fluorescent aerolysin. Am J Clin Pathol 2000;114:459-66.

7. Moyo VM, Mukhina GL, Garrett ES, Brodsky RA. Natural history of paroxysmal nocturnal haemoglobinuria using modern diagnostic assays. Br J Haematol 2004;126:133-8.

8. Hall C, Richards S, Hillmen P. Primary prophylaxis with warfarin prevents thrombosis in paroxysmal nocturnal hemoglobinuria (PNH). Blood 2003;102:3587-91. 